\title{
Comparative Analysis of Wood Usage by Artists and Building Professionals: Defects and Preservations
}

\author{
Michael Abiodun Oyinloye, Afeez Babatunde Siyanbola* and Adeyemi Adedola Olayinka \\ Department of Fine and Applied Arts, Olabisi Onabanjo University Ago-Iwoye, Nigeria \\ *Corresponding author: Afeez Babatunde Siyanbola, Department of Fine and Applied Arts, Olabisi Onabanjo University, Ago-Iwoye, \\ Ogun State, Nigeria
}

\begin{abstract}
This paper is focused on exploring the usage of wood types in the field practice of artists and building professionals. The paper enunciated the different types of woods and specific uses in relation to the strength and toughness. The importance of wood in the three disciplines, was identified and the appropriate preservation techniques used in safeguarding these from deterioration and rottenness were highlighted. Study considered availability of wood structure and aesthetic values derived from them. Apa has $90 \%$ use in artistic work, while 30\% in architecture and construction work respectively. Iroko has $60 \%$ usage in artistic work, architecture and construction work respectively. Omo has 30\% usage in artistic works, and $90 \%$ in architecture and construction work respectively. The paper analyses wood types, characteristics, defect in wood and wooden objects and simple techniques of combating and preserving them. Generally, availability of wood in the environment enhances its versatility. Observation shows that agents of deterioration in wood can be controlled in order to prolong the lifespan of wood already in use by artists, architects and building engineers.
\end{abstract}

Keywords: Aesthetics; Defect Preservation; Construction

\section{Introduction}

Wooden objects are durable and suitable for different purposes both indoor and outdoor. Wood has always been an integral part of man's development right from time immemorial to the present age. Wooden product is vital to the survival of humanity. Timbers are useful for fuel, bridges and tools for different occupations from the earliest period to the present. Wood has been exploited by man since the Upper Paleolithic period for fashioning tools, shelter, artist and religious objects $[1,2]$ Wood has also been an important construction material since human began building shelters, houses and boats. Most ferries were built of wood until 1800s, houses were also commonly timber-framed, and subsequently in the recent time wood utilized in producing paper and even clothing. Also, tree trunks were used to cross the river as demonstration of ancient age engineering. Ancient Egypt and Mesopotamia (Ancient Iraq) originated the earliest practices of Civil Engineering between 4,000 and 2,000BC when humans decided to abandon nomadic lifestyle with the beginning of the construction of shelter. During this period, transportation became gradually important leading to the development of the wheel and marine transportation (Figure 1).

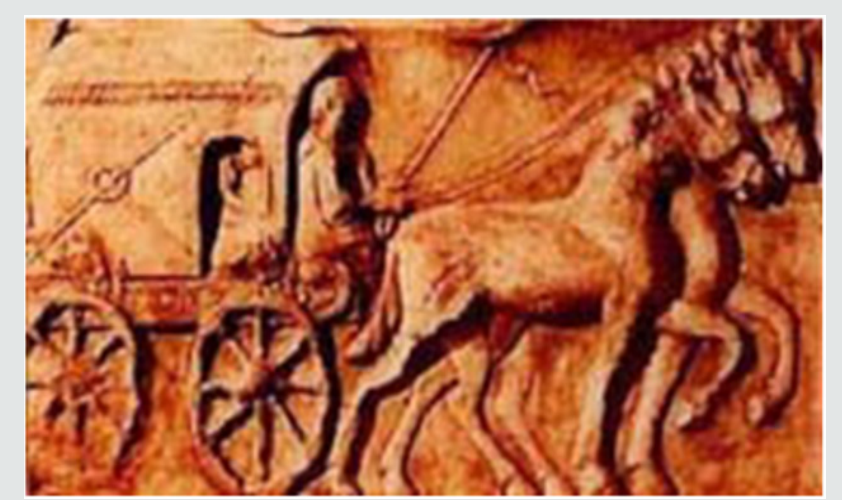

Figure 1: Ancient Egypt wheel invention. Source: [22].

Construction Engineering overtimes has advanced into several branches into the following specializations; building and Bridge Engineering, Concrete Engineering, Highway Engineering, Hydraulics, Marine Engineering, Piles Engineering, Soil Engineering, Steelworks, Surveying and Timber Engineering. Therefore, this paper highlights the Building and Timber Engineering aspect of 
Civil Engineering, Architecture and wooden sculpture under Fine and Applied Arts with a view to enunciate major importance of wood to these mentioned professions. The objectives are to espouse major wood types, uses and treatment as applicable to art, architecture and engineering.

\section{Availability of Wood and Aesthetic values}

Woods is evidently apparent in the day to-day human life; it serves a lot of purposes for humanity. The traditional African artist acknowledge the aesthetic value in wood being a critical necessary in producing his craftworks. Though, most arts and architectural objects in the earliest period were produced for functional purposes yet they are artistically appealing to the pleasure of human being. For example, the wooden house-post, door panels, sculptural objects of religion use, King's stool, staff, drum of different shapes were built to attract the users. There is evidence of wooden objects that are eye-catching and useful for socio-cultural purposes of the people in the community where they were made. These wooden objects are well-kept in the national museums as historical objects. Woods are used to create various artistic forms and useful objects in homes, palaces and shrines as religious objects. While some are musical tools and household utensils in ancient times, and subsequently in the contemporary time some are transformed into paper and even clothing [3].

The inquisitive nature of man about his environment for survival led to the detection of different wood types, and their suitability of purposes. For example, the art of carving ekpu ancestral wooden figure in Oron clan where there is well forested landscape in AkwaIbom State, led to the discovery of sacred Oko tree Coulaedulis and Pterocarpous Soyauxii a type not used for firewood because, it can resist termite attack, and other agent of deterioration [4]. The Ere Ibeji figurine, surrogate twin figure was popular among the Yoruba culture is usually created with Irena (Holarrhena floribunda) [4]. Basically, the specific uses of woods are known to Artists, Architects and Civil Engineers according to their experience and exposures in the respective disciplines.

\section{Wood structure and its processing property}

Brostow et al. [5] stated that wood possesses the same fundamental composite structure as some of the best man made materials developed from it (Figure 2). Timber is broadly utilized in the construction processes especially in the areas of non-standard scaffolding and concrete form. The advent of precast reinforced concrete and other progressive materials as well other usage of wood, in roof and housing construction. Arguably, wood is one of the most valuable raw materials supplied by nature for the construction industry. The uses may be classified into decorative (Artist also share this), functional and structural. Table 1 show the various types of wood found in South-western part of Nigeria and their uses. The common roof bind materials in this area are timber, concrete, raffia palm and steel. Roofs are constructed with wood than any other structural materials. The widespread use of wood for roof construction has both economic and aesthetic basis. Oyetola posited that timber is known for its beauty, versatility, strength, durability and workability (Tables 1-4) [6].

Table 1: Types of wood in Southwest, Nigeria Source: [6].

\begin{tabular}{|c|c|c|c|c|c|}
\hline \multirow{2}{*}{ S/No } & \multirow{2}{*}{ Wood Type (Local Name) } & \multirow{2}{*}{ Botanical Name } & \multicolumn{3}{|c|}{ Purpose of Use } \\
\hline & & & Decorative & Functional & Structural \\
\hline 1 & Afara & Terminalia ivorensis & - & $*$ & * \\
\hline 2 & Apado & Conluoa grandiflora & & & * \\
\hline 3 & Erun & Erythroplum suaveolens & & & $*$ \\
\hline 4 & Agbonyin & Piptadeniastrum africanum & * & & * \\
\hline 5 & Akokokoigbo & Lovoa trichiloides & & * & $*$ \\
\hline 6 & Teak & Tectona grandis & & * & $*$ \\
\hline 7 & Omo & Cordial millenii & * & $*$ & $*$ \\
\hline 8 & Mahogany & Khaya ivorensis & & $*$ & $*$ \\
\hline 9 & Agba & Gossweilero balsamefurum & & & * \\
\hline 10 & Arere & Triplochiton acleroxylon & & & * \\
\hline 11 & Apa & Afzelia Africana & & & $*$ \\
\hline 12 & Oro & Nassogoidonia papaverifera & & & $*$ \\
\hline 13 & Araba & Ceiba pentandra & & & $*$ \\
\hline 14 & Ayo & Holoptalea grandis & & & $*$ \\
\hline 15 & Ayin & Anogeissus leicarpus & & & $*$ \\
\hline 16 & Opepe & Nauclea diderrichii & & $*$ & $*$ \\
\hline 17 & Iroko & Melicea excels & & $*$ & $*$ \\
\hline
\end{tabular}


Table 2: Scoring of wood based on usage (Artistic Work). Source: [4].

\begin{tabular}{|c|c|c|c|c|c|}
\hline \multirow{2}{*}{ S/No } & \multirow{2}{*}{ Wood Type (Local Name) } & \multicolumn{3}{|c|}{ Purpose of Use } & \multirow{2}{*}{ Percentage Score (\%) } \\
\hline & & Decorative & Functional & Structural & \\
\hline 1 & Apa & $*$ & $*$ & $*$ & 90 \\
\hline 2 & Ahun & & * & & 30 \\
\hline 3 & Eriri & & * & & 30 \\
\hline 4 & Erinmado & & $*$ & * & 60 \\
\hline 5 & Iroko & & $*$ & $*$ & 60 \\
\hline 6 & Irena & & $*$ & $*$ & 60 \\
\hline 7 & Ire & * & * & & 60 \\
\hline 8 & Ole & $*$ & $*$ & $*$ & 90 \\
\hline 9 & Omo & * & & * & 30 \\
\hline 10 & Oriri & $*$ & & & 30 \\
\hline
\end{tabular}

Table 3: Scoring of wood based on usage (Architectural Work). Source: [6].

\begin{tabular}{|c|c|c|c|c|c|}
\hline \multirow{2}{*}{ S/No } & \multirow{2}{*}{ Wood Type (Local Name) } & \multicolumn{3}{|c|}{ Purpose of Use } & \\
\hline & & Decorative & Functional & Structural & \\
\hline 1 & Afara & $\bullet$ & & $*$ & 90 \\
\hline 2 & Apado & & & * & 30 \\
\hline 3 & Erun & & & $*$ & 30 \\
\hline 4 & Agbonyin & $*$ & & * & 60 \\
\hline 5 & Akokokoigbo & & $*$ & $*$ & 60 \\
\hline 6 & Teak & & $*$ & $*$ & 60 \\
\hline 7 & Omo & $*$ & * & $*$ & 90 \\
\hline 8 & Mahogany & & * & * & 60 \\
\hline 9 & Agba & & & $*$ & 30 \\
\hline 10 & Arere & & & * & 30 \\
\hline 11 & Apa & & & $*$ & 30 \\
\hline 12 & Oro & & & $*$ & 30 \\
\hline 13 & Araba & & & * & 30 \\
\hline 14 & Ayo & & & * & 30 \\
\hline 15 & Ayin & & & $*$ & 30 \\
\hline 16 & Opepe & & * & * & 60 \\
\hline 17 & Iroko & & * & * & 60 \\
\hline
\end{tabular}

Table 4: Scoring of wood based on usage (Construction Work).

\begin{tabular}{|c|c|c|c|c|c|}
\hline \multirow{2}{*}{ S/No } & \multirow{2}{*}{ Wood Type (Local Name) } & \multicolumn{3}{|c|}{ Purpose of Use } & \multirow{2}{*}{$\begin{array}{l}\text { Percentage } \\
\text { Score }\end{array}$} \\
\hline & & Decorative & Functional & Structural & \\
\hline 1 & Afara & $\cdot$ & $*$ & $*$ & 90 \\
\hline 2 & Apado & & & $*$ & 30 \\
\hline 3 & Erun & & & * & 30 \\
\hline 4 & Agbonyin & $*$ & & $*$ & 60 \\
\hline 5 & Akokokoigbo & & * & * & 60 \\
\hline 6 & Teak & & $*$ & $*$ & 60 \\
\hline 7 & Omo & $*$ & $*$ & $*$ & 90 \\
\hline 8 & Mahogany & & * & * & 60 \\
\hline 9 & Agba & & & $*$ & 30 \\
\hline 10 & Arere & & & * & 30 \\
\hline
\end{tabular}




\begin{tabular}{|c|c|c|c|c|}
\hline 11 & Apa & & $*$ & 30 \\
\hline 12 & Oro & & $*$ & 30 \\
\hline 13 & Araba & & * & 30 \\
\hline 14 & Ayo & & $*$ & 30 \\
\hline 15 & Ayin & & * & 30 \\
\hline 16 & Opepe & $*$ & * & 60 \\
\hline 17 & Iroko & * & * & 60 \\
\hline
\end{tabular}

\section{Wood characterization}

Wood is the skeletal tissue of higher green plant. It has two main constituents: Lignin and cellulose fibrils $[3,7]$. The presence of lignin in different degrees support reinforcements and cellulose preservations (Figure 2). Wood absorbs moisture, from the atmosphere. Wood is also has physical characteristics in different directions which are not similar. Smithsonian [8] observed wood as naturally very durable in moderately sheltered environment. Researchers have shown that carved wooden objects may last for thousands of years without substantial change, if it is not exposed to direct ray of light and water contact is avoided on it. However, biological deterioration of wood or wooden objects is found principally in the activities of insects and fungi [4]. Wood and their uses can generally be grouped into two; hard and soft wood.
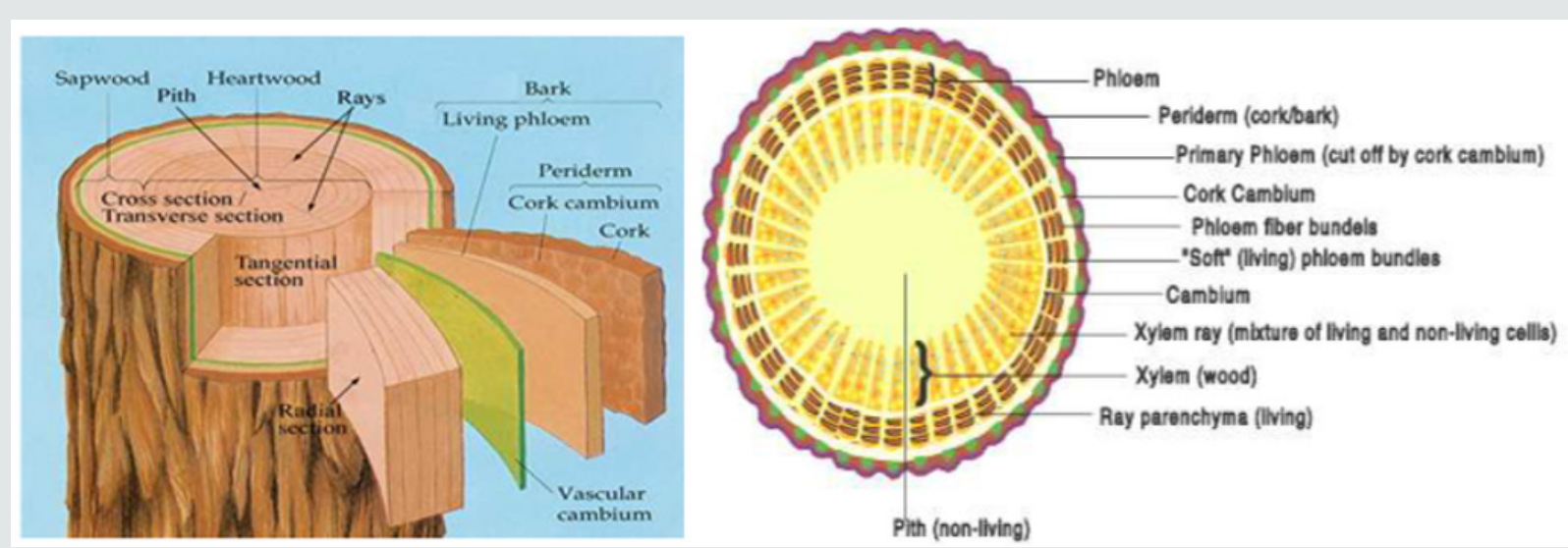

Figure 2: Structure of a tree trunk. Source: Brostow, Datashvili and Miller [5].

Hardwoods generally comprise deciduous trees; while softwoods, comprise of conifers. The density, porosity, hardness, strength, and flexibility of wood differ from species to species and to a lesser degree within species from the age and part of the tree and where it has grown. Research has also shown that deterioration in woods manifests as shrinkage, warping and cracking, which result from the loss of bound water within the cell walls [1] (Figures 3-5).

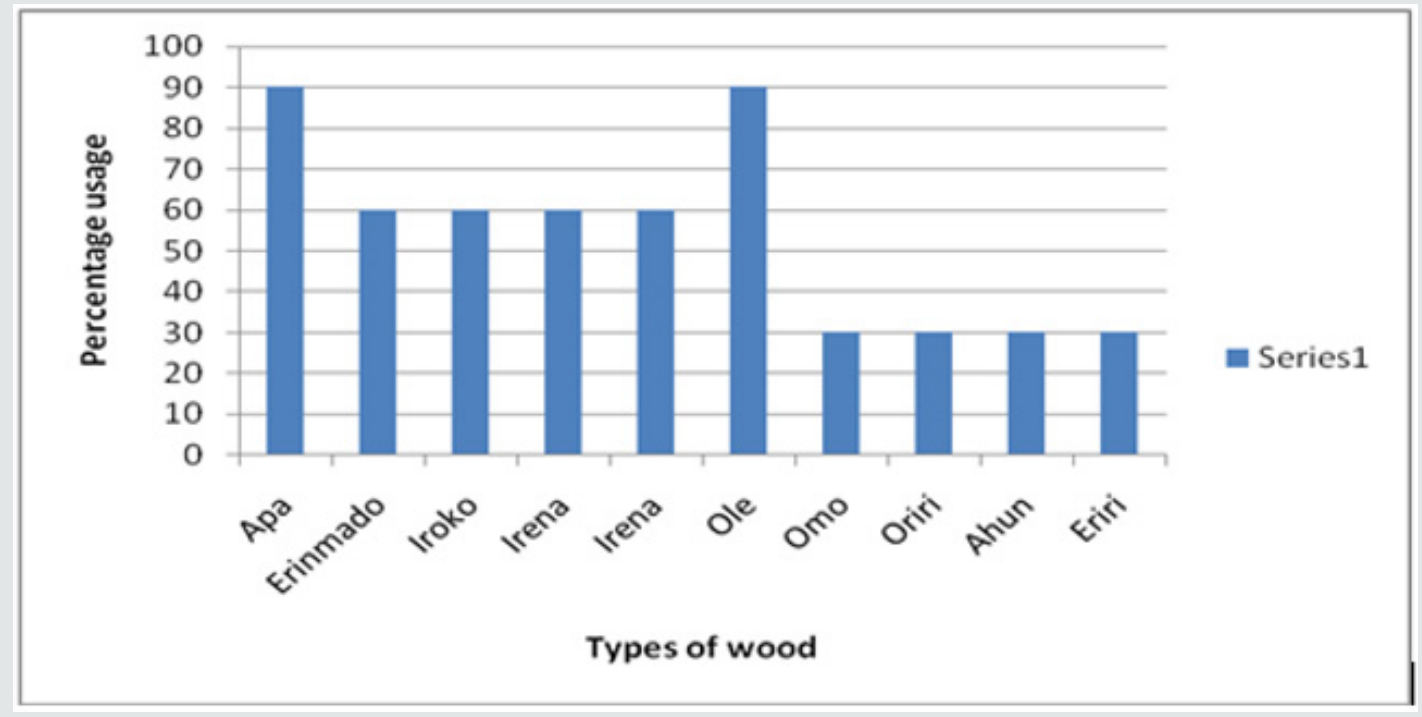

Figure 3: Artist percentage usage of wood types. 


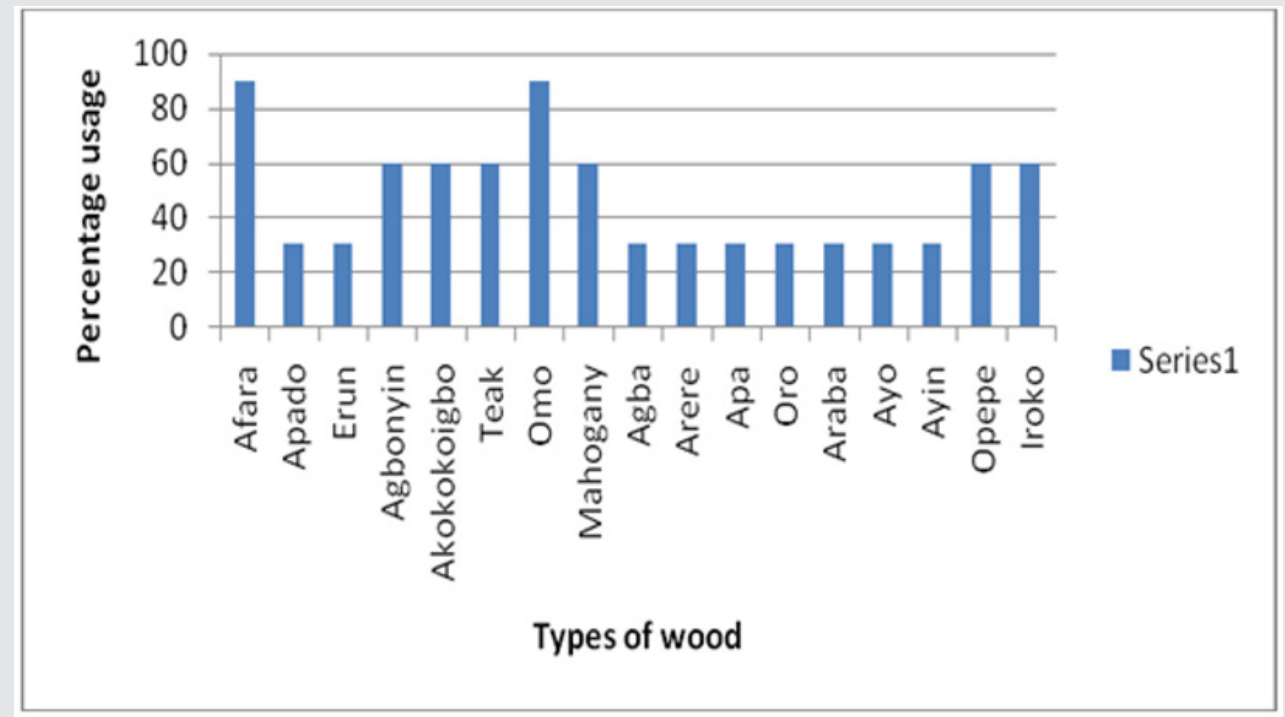

Figure 4: Architectural percentage usage of wood types.

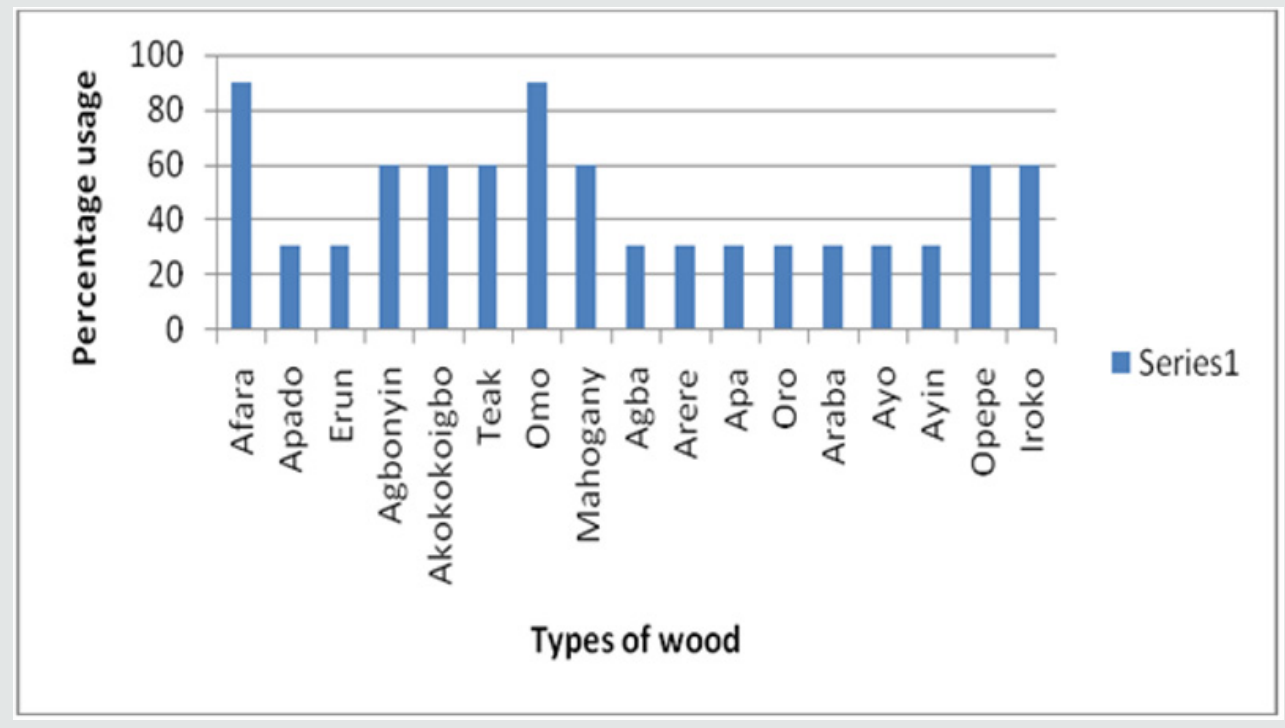

Figure 5: Construction percentage usage of wood types.

\section{Common defects in wood/wooden objects}

Different groups of organisms are usually observed within the anatomical structure of the wood to be responsible for these defects. However, their identifications and method of attack are difficult to establish especially among groups like fungi, bacteria, and animals such as insects or nematodes which are responsible for degradation processes of living and dead plants in almost all environments [9-12]. Three groups of likely defects wood:

Due to natural forces

Due to defective seasoning and conversions

Due to attack by fungi and insects.

Due to natural forces: The following defects are caused by natural forces: a) Knots b) Shakes c) Wind cracks d)Upsets a) Knots: When a tree grows, many of its branches fall and the stump of these branches in the trunk is covered. In the sawn pieces of timber, the stumps of fallen branches appear as knots. Knots are dark and hard pieces. Grains are distorted in this portion. Figure 6 shows some types of knots. If the knot is intact with surrounding wood, it is called live knot. If it is not held firmly it is dead knot.

b) Shakes: Shakes are cracks in the timber which appears due to excessive heat, frost or twisting caused by wind during the growth of a tree. Depending upon the shape and the positions, shakes can be classified as star shake, cup shake, ring shakes and heart shakes (Figure 7).

c) Wind Cracks: These are the cracks on the outside of a log due to the shrinkage of the exterior surface. They appear as shown in Figure 8. 

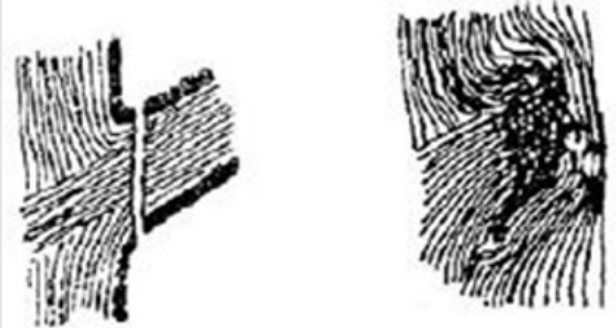

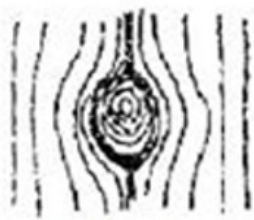

Live knot

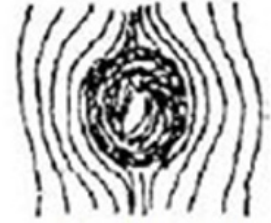

Decayed knots

Figure 6: Knots. Source: [22].
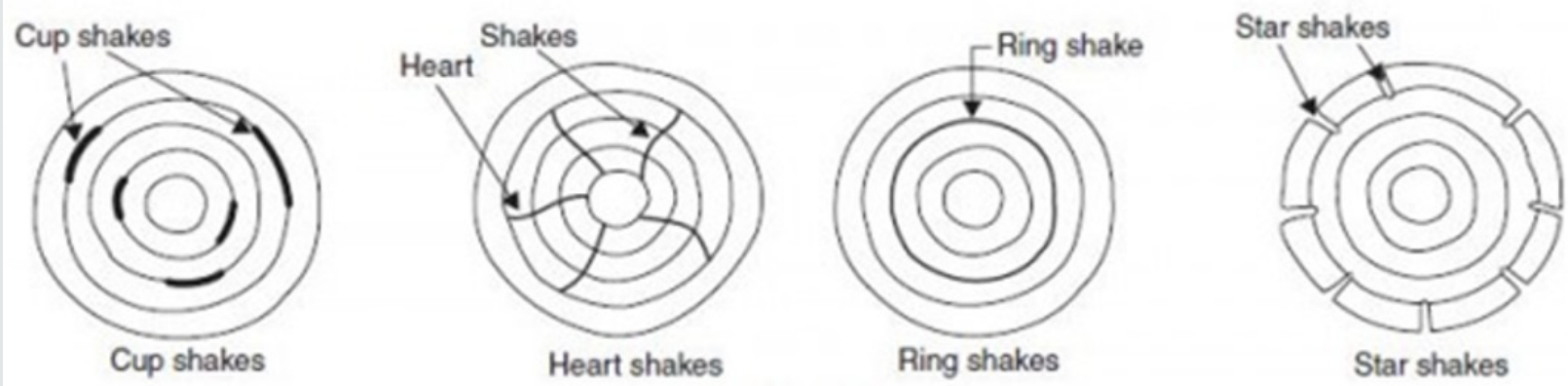

Figure 7: Shakes.Source: [22].

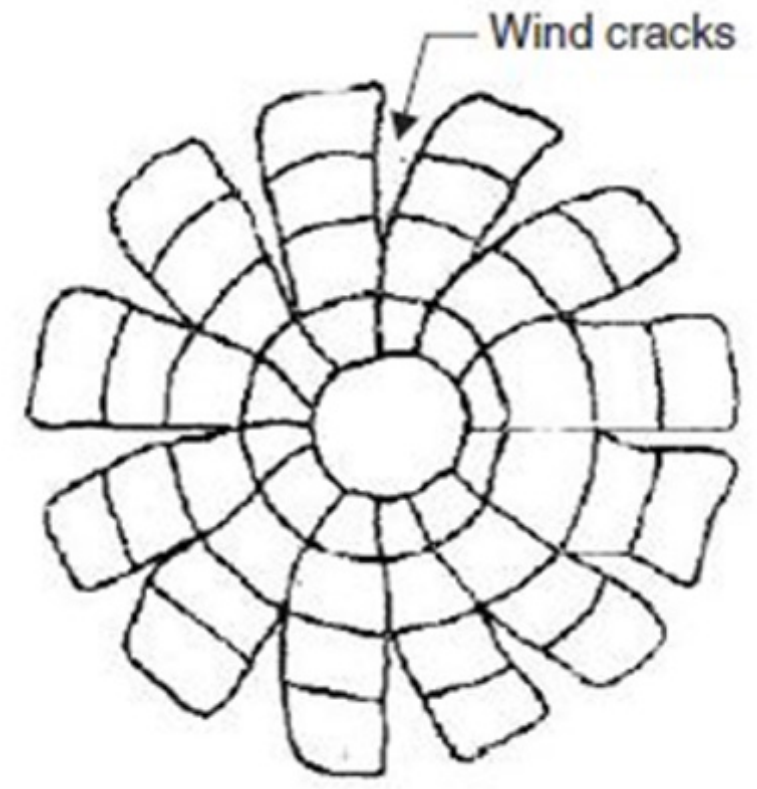

Figure 8: Wind cracks. Source: [22]. 


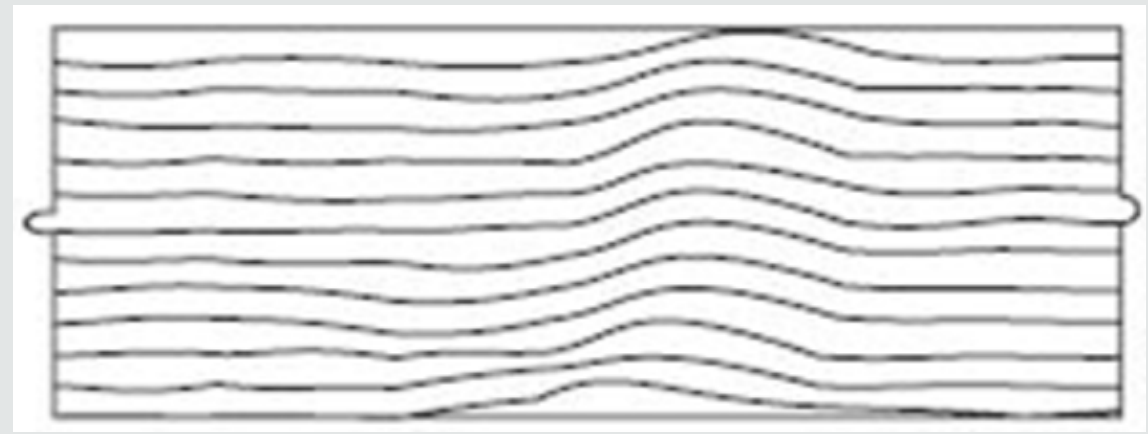

Figure 9: Upsets. Source: [22].

d) Upsets: Figure 9 shows a typical upset in a timber. This type of defect is due to excessive compression in the tree when it was young. Upset is an injury by crushing. This is also known as rupture.

Defects due to defective seasoning and conversion: If seasoning is not uniform, the converted timber may warp and twist in various directions. Sometimes honey combining and even cracks appear. These types of defects are more susceptible in case of kiln seasoning. In the process of converting timber to commercial sizes and shapes the following types of defects are likely to arise: chip marks, torn grain etc.

Defects due to fungi and insects attack: Fungi are minute microscopic plant organism. They grow in wood if moisture content is more than $20^{\circ} \mathrm{C}$ and exposed to air. Due to fungi attack rotting of wood, takes place. Wood becomes weak and stains appear on it. Beetles, marine borers and termites (white ants) are the insects which eat wood and weaken the timber. Some woods like teak have chemicals in their compositions and resist such attacks. Other woods are to be protected by chemical treatment.

Timber is a sustainable, economical, completely renewable, $\mathrm{CO}_{2}$ neutral organic material, which requires less energy to process than other construction materials. Wood is also a strong, aesthetically pleasing, and very durable material when properly maintained and used. However, under certain conditions of exposure or use particularly when it becomes wet, wood may be rapidly decomposed due to organic decay or natural weathering agents. Decay is caused by the action of fungal micro-organisms under adequate moisture and oxygen conditions for an extended period of time. The various effects of combinations of light, water, mechanical forces and heat, are covered in the blanket term weathering [13].

It is important to be familiar with the certain characteristics of wood. Wood, as an anisotropic substance, exhibits different degrees of hardness, toughness and softness [2]. It is been noted that changing in relative humidity may cause wood crack or distortion. Particularly on carved objects. Therefore, most reasonable way of preserving wooden objects is to avoid exposing them to wide variation in atmospheric humidity [4]. While fungi growth on wood is dependent on a degree of dampness that supplies necessary nutrients before it can thrive. Wood is attacked because it has become wet owing to inadequate provision of damp-proof courses. A preventive measure in this situation is to isolate the wood, introduce damp-proof agents, such as licensed oil, wax, or waterrepellent silicone vanishes. Also impregnate any part of wood buried under ground level and encased in water proof cement (e.g. Veranda post or house post).

It is also worthy of note that whenever moulds are growing on wooden object, they are caused by the ethnographical specimens, such as oil, grease, vanish, rather than on the wood itself. Such growth may be arrested by cleaning and applying fungicide on the object. Insects are the major agent of wood breakdown either in the museum home or roof of a structure. Insects or pests constitute a greater menace to wood or wooden objects than any other damaging factor because they are present everywhere in the environment. If it is not checked at early stage, the wood may fall into pieces. Signs of insects or pest are noticeable worm holes discharging powder and frass resembling fine sawdust [4].

Summarily, wood deterioration is centered on concentration of moisture content. Wood or wooden objects should not be allowed to be exposed to very harsh or moisture environment. Wood may well not be actively stabilized, but prevention of damage by desiccation, handling or fluctuating relatively humidity (RH) must be considered if work excavated with wood must last for a very longtime.

\section{Wood Preservation}

Untreated wood products do not last long because they are prone to fungal, bacterial and termite attacks, woods therefore are generally treated with a chemical preservative to prevent damage [14]. Consequently, differently treated wood products have found their way into the timber market. Pressure treated wood products have gained popularity because of their durability, especially in warm humid climates countries. Wood preservation is a way to increase the biological durability of wood by adding chemicals with a biocidal effect. The effects of such treatments are clearly dependent on concentrations. At specific biocide levels, fungi are either killed, or their ability to obtain nutrients through their enzymatic functioning is inhibited. Non-biocidal treatments act quite differently. Mechanisms such as moisture exclusion or hydrophobation retard or stop colonisation by fungi. Because these treatments are only effective above a certain level or when a certain degree of substrate modification is reached (heat treatment), it is seldom possible to establish a dose response curve [15]. 
To preserve wood a number of impregnation methods and impregnates are commonly used, singly or in combination [16,17]. Some identified preservatives are discussed below.

\section{Some identified preservatives}

Copper napththenate: Usually sold as a concentrate or solution ready to use. The concentrate is 8 percent copper, a viscous green liquid. For dip, soak or brush application it usually is diluted with mineral spirits or paint thinner to a 1 percent copper solution (temperate zones) or 2 percent copper solution (subtropical zones). It may bleed through some paints and should be allowed to thoroughly dry before being painted.

Copper-8-quinolinolate: Less effective than copper napththenate, yet less hazardous and can be used to preserve wood contacting foodstuffs (refrigerator cars, food-processing plants). It can be obtained as a water or solvent-soluble concentrate or ready to use. A solvent-type solution of about 0.045 percent copper is commonly used for brush and dip treatments.

Acid copper chromate: Used in some commercial treatment plants, already treated wood can be found in certain areas. It can be applied by brushing, soaking or dipping, but wood is more durable if pressure treated. However, some authors recommend purchasing commercially treated wood, using dust masks when sawing, and disposing of scrap in landfills rather than burning [18].

Caution: Most wood preservatives are classified as pesticides and may be injurious to humans or animals, plants, fish or other wildlife. All must be used according to the label which is the law.

Chromated copper arsenate (CCA): Chromated Copper Arsenate (CCA) is a water-based pressure treatment, where the copper $(\mathrm{Cu})$ acts as a fungicide and the arsenate, an insecticide [19]. Chromium ( $\mathrm{Cr}$ ) is used to fix the other two elements to the cellulose and other components of the wood. Arsenic is generally used in two anionic forms, arsenite [As (III)] and the more mobile arsenate $[\mathrm{As}(\mathrm{V})]$. Copper exists mostly in the cationic form $\mathrm{Cu}^{2+}$, and although $\mathrm{Cr}$ is a cation, it commonly exists in two anionic forms, the more mobile and toxic chromate ions from $\mathrm{Cr}$ (VI), and the less mobile and toxic $\mathrm{Cr}$ (III).

\section{Summary, Conclusion and Recommendations}

The importance of wood to artist, architects and building engineers can never be over emphasized. Woods and wooden objects have been seen by this study has been widely available in most part of the continents and when thoroughly worked upon has great aesthetic qualities and values. The characteristics and structure of woods has also encouraged the versatility in its usage ranging from carving various objects to its uses in different aspects of construction. Although there are various defects that can occur to woods during their lifetime but this study emphasized that the effects of these defects can be totally nullified if appropriate actions are taken at the right time to engage specified wood preservatives. These preservatives are available in different range, brand and capacity so that they can be selected to target specific wood defects without giving room for trial by error methods [20, 21, 23].
For woods to continue to benefit humanity appropriately, this study recommends the following: that more research works should be carried out on woods and their products; aforestation should be greatly encouraged by all nations to counter the effects of deforestation to get wood products; focus on constant orientation programs by national governments and other stakeholders on sustainable values of wood products, retraining programmes for professionals in the wooden industry on selection of appropriate preservatives to prolong the shelve life of trees where necessary.

If the above recommendations are appropriately adhered to, the use of wood as forest resources will greatly make the built environment to develop sustainable and thereby contribute to the current research efforts at combating the challenges of unsustainable development of the built environment.

\section{References}

1. Feilden BM (1979) An introduction to conservation of cultural property. UNESCO, Rome, Italy.

2. Plenderleith HJ, Werner AE A (1974) The conservation of antiquities and works of art. Oxford University Press, London, United Kingdom.

3. Taylor M (1981) Wood in archaeology. Shire publications Ltd, London, United Kingdom.

4. Oyinloye MA (2015) Conservation of wooden objects in the Nation Museums in Lagos and Oron, Nigeria; Unpublished $\mathrm{PhD}$. thesis, Department of Archaeology and Anthropology, University of Ibadan, Ibadan, Nigeria.

5. Brostow, W, Datashvili T, Miller H (2010) Wood and Wood Derived Materials. Journal of Materials Education 32 (3-4): 125-138.

6. Adeosun SO (2013) Wooden materials in building projects: Fitness for roof construction in Southwestern Nigeria. Journal of Civil Engineering Construction Technology 4(7): 217-223.

7. Cronyn JM (1990) The elements of archaeology conservation. Routledge, London, United Kingdom.

8. Smithsonian Museum Conservation Institute (2010) Biological Deterioration and Damage to Furniture \& Wooden objects.

9. Blanchette RA (2000) A review of microbial deterioration in archaeological wood from different environments. Journal of International Biodeterioration and Biodegradation 46(3): 189-204.

10. Schuttz TP, Nicholas OD (2002) Development of environmentally preservatives based on the combination of organic biocedes with cooxidants and metal chelators. Journal of Phyton Chemistry 61(5): 555560 .

11. Koestler RJ, Koestler VR, Charola AE, Nieto-Fernandez FE (Eds.), (2003) Art, Biology and Conservation: Biodeterioration of Works of Art. Metropolitan Museum of Art, New York, USA.

12. Caneva G, Nugari MP, Salvadori O (2008) Plant Biology for Cultural Heritage: Biodeterioration and Conservation. The Getty Conservation Institute, Los Angeles, USA.

13. HyvönenA, Piltonen A, Niinimäki J (2005) Biodegradable Substances in Wood Protection. In Anneli Jalkanen and Pekka Nygren (Eds.) Sustainable use of renewable natural resources - from principles to practices. Department of Forest Ecology Publications, University of Helsinki, Finland.

14. Craig Rodney, B Eaton, Thorp CH (2001) Effects of chromated copper arsenate (CCA) Wood preservation earley fouling community formation. African Journal of Biotechnology 6(17): 1100-1013.

15. Van A, Stevens M (2000) Increased biological durability differs for traditional wood preservation and new non-biocidal systems (NBS). 
The International Research Group on aWood Preservation, IRG/WP 0020212 p. 11.

16. Ulvcrona T (2006) Impregnation of Norway spruce (Picea abies L. Karst.) wood with hydrophobic oil. Unpublished PhD thesis, Swedish University Umea, Sweden.

17. Sibel Y, Ümit Y, Eylem D, Ali T, Engin G (2010) The Effects of Pre-Acid Treatment on Preservative Retention And Compression Strength Of Refractory Spruce Wood Impregnated With CCA And ACQ. Journal of Wood Research 55(3): 93-104

18. Sanford MT (2003) Preserving Woodenware in Beekeeping Operations. Document ENY-125, a series of the Entomology and Nematology Department, Florida Cooperative Extension Service, Institute of Food and Agricultural Sciences (IFAS), University of Florida, USA.
19. Chirenje T, Ma LQ, Szulczewski M, Hendry K, Clark C (2004) Retention of $\mathrm{As}, \mathrm{Cu}$, and $\mathrm{Cr}$ leached from CCA-treated wood products in selected Florida soils. Proceedings of conference on Environmental Impacts of Preservative-Treated Wood held at Florida Center for Environmental Solutions Gainesville, Florida, USA.

20. Moskal-del Hoyo M, Wachowiak M, Blanchett RA (2010) Preservation of fungi in archaeological charcoal. Journal of Archaeological Science 37: 2106-2116.

21. Moskal-del Hoyo M, Wachowiak M, Blanchett RA (2010) Preservation of fungi in archaeological charcoal. Journal of Archaeological Science 37: 2106-2116.

22. Www.thecivilengg.com/History.php

23. Www.reference.com/home-garden/common defects - timber (c) (i) This work is licensed under Creative

To Submit Your Article Click Here:

Submit Article

DOI: $10.32474 / J A A S .2020 .01 .000117$

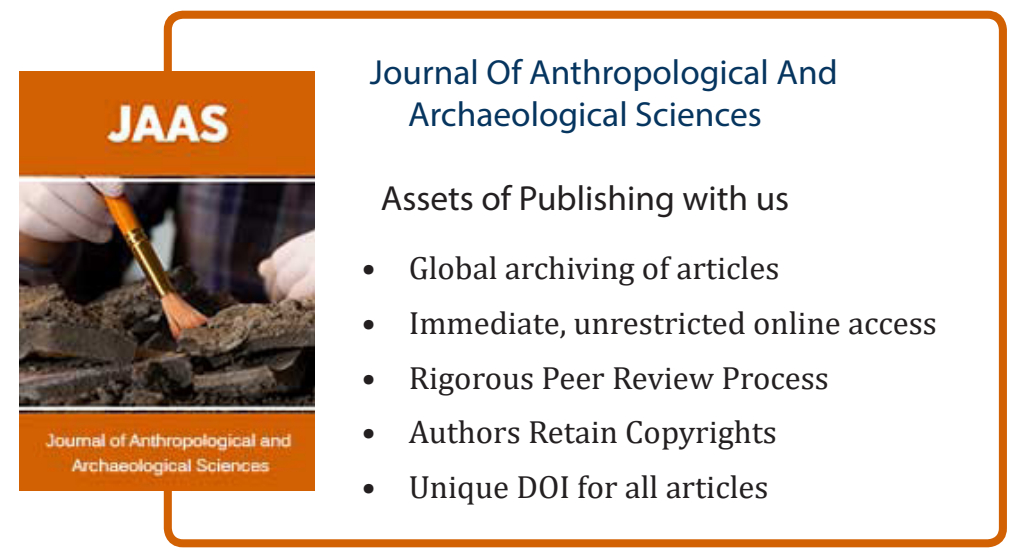

